\title{
An Innovative Study on Problem-based Learning and Literature Teaching
}

\author{
Yan Jiang \\ School of Foreign Languages \\ Wuhan University of Technology \\ Wuhan, P.R.China, 430070 \\ jiangyanwut@126.com
}

\begin{abstract}
An innovative method of Problem-based Learning (PBL) in literature teaching has been proposed, consisting of seven equally important stages: group setting, problem identification, idea generation, learning issues, self-directed learning, synthesis and application, reflection and feedback. An empirical research has been conducted to evaluate the effectiveness of PBL compared with traditional literature teaching approach and instruction. To illustrate how each of these stages functions, one experimental lesson on Jane Eyre written by Charlotte Brontë has been introduced. Based on the results of the current research, the conclusion has been drawn that PBL is more effective than traditional literature teaching approach and instruction.
\end{abstract}

Keywords-Problem-based Learning; Literature teaching; Experimental research; Student-centered approach

\section{INTRODUCTION}

Problem-based Learning (PBL) was initiated by Professor Barrows at McMaster University in Canada in the 1960s. The year of 1980 witnessed the publication of the book "Problembased Learning: An Approach to Medical Education” written by Howard S. Barrows MD[1], presenting the scientific basis of problem-based learning and going on to describe the approaches to problem-based medical learning that had been developed over the years at McMaster University, largely by Barrows and Tamblyn. PBL is a student-centered approach which attaches much importance to learning needs and selfdirected enquiry. By integrating theory and practice, the students apply knowledge in an effort to develop a solution to a defined problem. Since its inception, PBL has been applied in the teaching of architecture, law, economics, business management, psychology in western universities. Currently PBL still remains its popularity in the field of higher education, which has drawn much attention due to the great theoretical significance and the wide practical value as well. In the previous decade, many foreign researchers (Muhammad Athar Hussain, Muhammad Nafees, Nabi Bux Jumani, 2009[2]; Olivera Gajic, 2014[3]) have conducted empirical studies to explore the effectiveness of PBL in literature teaching. At the same time, the researches on PBL in China go from the study on college English teaching in general (Wang Jie, 2005[4]; Miao Zhangyan, 2014[5]) to the specific study on English writing (Zhang Lei, 2007[6]; Chen Limin, 2014[7]), English listening (Chen Yanling, 2013[8]), English speaking (Li Jing, 2013[9]) and English reading (Wang Wei, 2014[10]). However, no researches were concerned with PBL and literature teaching in China. Therefore, in accordance with the characteristics of Chinese learners, the current study intends to conduct theoretical discussion and empirical research on the application of PBL in literature teaching.

\section{PBL AND LitERATURE TEACHING}

Problem-based Learning (PBL) is viewed as critical, reflective, and constructive. Under the teacher's guidance and assistance, the students take the initiatives to study literary works, reflect on the proposed problems and eventually explore the problem-solving methods. In this research, PBL consists of seven equally important stages: group setting, problem identification, idea generation, learning issues, self-directed learning, synthesis and application, reflection and feedback. To illustrate how each of these stages functions, one experimental lesson was conducted on Jane Eyre written by Charlotte Brontë. With the help of PBL, the lesson achieved a marvelous teaching effect.

\section{A. Group setting}

The lesson began with the first stage in which the teacher was about to group the students in appropriate ways so as to promote PBL. Guided by the principle of "be homogeneous among groups and heterogeneous within a group”, the teacher divided the whole class into five mixed proficiency groups, each of which was composed of two students with an advanced level, an elementary level, and an intermediate level respectively. Due to the teacher's justification of the use of small groups for PBL, the students agreed upon learner groupings.

\section{B. Problem identification}

The second stage touched upon the life of Charlotte Brontë. The problems were identified with such five aspects as childhood, schooling, job, love and literary works. Each group was in charge of one aspect of her life. Once students were in a group, they brainstormed to understand the nature of the problem. In this case, the role distribution was based on "who knows what to do". They assigned themselves roles and responsibilities for resolving specific problems. 


\section{Idea generation}

In the third stage, various ideas were generated within the groups where many heads were better than one or two. The students working in groups helped each other to learn. Thus, cooperative groups encouraged discussion of problem-solving techniques and avoided the embarrassment of students who had not yet mastered all of the skills required. Therefore, the students were informed that Charlotte Brontë lived a lonely and deprived childhood; she attended charity schools but her real education was at home; she was once a teacher in Roe Head and later became a governess; she fell in love with a married man; her first novel The Professor was rejected by publishers, and her second novel Jane Eyre was published in 1847, although it was not initially well received. A majority of the students held an opinion that the life of Charlotte Brontë exerted a great influence on her literary writing.

\section{Learning issues}

During the fourth stage, the learning issues were concerned with the novel Jane Eyre from the perspectives of bildungsroman and feminism. The teacher made it clear that bildungsroman meant life-story of a protagonist from childhood through a series of trials to maturity, thus one issue was the comparison between Charlotte Brontë and Jane Eyre, the writer and the heroine. The other issue "feminism" dealt with Jane Eyre's female qualities in the novel.

\section{E. Self-directed learning}

The fifth stage was characterized by studying independently. Students were given opportunities to figure out the learning issues by themselves, receiving help only when necessary. Concerning the bildungsroman, the students had the prior knowledge about the life of Charlotte Brontë, yet they needed to find out new knowledge in order to solve the problem of feminism. Hence, they consulted various resources including books, articles, reports, web sites and the teacher.

\section{F. Synthesis and application}

In the sixth stage, the students did more than just listen: they read, wrote, discussed, and were engaged in solving problems. To be actively involved, they engaged in such higher-order thinking tasks as analysis, synthesis, and evaluation. In addition, they role-played the conversation between Jane Eyre and Mr. Rochester in Chapter 23 of the novel. In doing so, they got a better idea of the concepts and theories being discussed. Using various sources, student teams presented witnesses to construct their plots, and prepared questions for cross-examination. For example, "Do you believe in feminism?" "Are you a feminist?" "Can men be feminists too?" "What has this got to do with novels?" "Why did feminist writings come out as a boom during Victorian Period?" "Is the 'madwoman in the attic' the true heroine of Jane Eyre?"

\section{G. Reflection and feedback}

The last stage witnessed the students' reflection and feedback by means of a debate on whether "Lady First" is an outdated concept or not. Actually, formal debates provided an efficient structure for class presentations when the subject matter could be easily divided into opposing views or "Pro/Con" considerations. Students were assigned to debate teams, given a position to defend, and then asked to present arguments in support of their position. Some students did not think that "Lady First" is an outdated concept for the sake of polite manners, while others agreed that "Lady First" is an outdated concept from a feminist perspective. Eventually they remembered that there is no "correct" solution to real life problems since all solutions will have their advantages and disadvantages.

\section{EXPERIMENT DESIGN}

The present research has examined the learning effect of Chinese learners of foreign literature at the university level in PBL situation. Its objective includes evaluating the effectiveness of PBL compared with traditional literature teaching approach and instruction.

\section{A. Hypotheses}

The formulation of the two hypotheses, null and alternative, was based on the following reasoning:

1) $\mathrm{H}_{0}: U_{\mathrm{a}}=\mathrm{U}_{\mathrm{b}}$

More specifically, the null hypothesis (i.e., H0 in the formula) suggests that there exists no significant difference between PBL and traditional literature teaching approach and instruction.

\section{2) $\mathrm{H}_{1}: \mathrm{U}_{\mathrm{a}} \neq \mathrm{U}_{\mathrm{b}}$}

On the other hand, the alternative hypothesis (i.e., $\mathrm{H} 1$ in the formula) implies that the effect of PBL is significant, namely, PBL is more effective than traditional literature teaching approach and instruction.

\section{B. Subjects}

The whole investigation involved a teaching experiment which compared one class that studied with PBL versus another class that was taught with the traditional literature class instruction method. The present research contained a total of 60 subjects who formed two groups, namely, experimental group and control group. The subjects were third-year English majors in Wuhan University of Technology. None of the subjects knew the purpose of this study in advance. The students in both control and experimental groups shared similar English learning background and showed no significant difference in their English proficiency, which has been proved to be true through the pre-test before the teaching experiment.

\section{Procedure}

This research was a classroom-based research, which lasted two months. In order to control the elements of the teaching research, the teacher taught both the control and experimental groups. The students in experimental group were taught by means of PBL, which was manifested by group setting, problem identification, idea generation, learning issues, selfdirected learning, synthesis and application, reflection and feedback. The above-mentioned experimental lesson on Jane 
Eyre written by Charlotte Brontë elucidated how each of these stages functioned.

With regard to the control group, the situation was widely divergent. The students in the control group learned the same novel as those in the experimental group. But they were taught in a totally different way. The teacher emphasized on introduction to the writer and explanation of the literary works, which was the traditional dominant approach in literature teaching. When teaching the materials on the textbook, the teacher gave the lectures for most of the time. When the students retold the story of the novel, they practiced individually. That is, nearly no PBL happened during the study of literary works. Certainly, they were asked to sit for pre-test and post-test that were identical to the two test papers respectively in the experimental group.

\section{Data Analysis and Discussion}

The data sources used in this current study were test scores. Thus, the major results which emerged from the experiment are reported and further discussions about the two different groups are addressed.

\section{A. Experimental results and interpretation}

The results of this study are presented according to different data sources in the teaching research. They are test scores including pre-test and post-test. The data got from the pre-test is analyzed by means of SPSS software. The results can be shown clearly in Table 1 and Table 2 .

\section{1) Result from pre-test}

According to the nature of the research, the related theory in statistics and SPSS software, since the samples are relatively small and the groups are independent, the appropriate test is the t-test for independent samples. The critical value of t-test for the 5 percent level and $58 \mathrm{df}$ (degrees of freedom) in a twotailed test is 2.000 . The calculated value of t shown in Table 1 does not exceed the critical value. In this case, the means are not significantly different at the 5 percent level. Thus a conclusion can be drawn here that there is no significant difference between the two groups of learners in English proficiency before the teaching research.

TABLE I. COMPARISON OF ACHIEVEMENTS BETWEEN THE TWO GROUPS

\begin{tabular}{|l|l|l|l|}
\hline \multirow{2}{*}{} & \multicolumn{2}{|l|}{ Group } & \multirow{2}{*}{$\mathrm{t}$} \\
\cline { 2 - 3 } & \multicolumn{2}{|l|}{ experimental control } & \multirow{2}{*}{0.886} \\
\hline Mean & 65.350 & 63.967 & \\
\hline SD & 6.245 & 5.387 & a. Note: maximum score $=100 \mathrm{n} 1=30 \mathrm{n} 2=30 \mathrm{P}<.05 \mathrm{df}=58$ \\
\hline
\end{tabular}

\section{2) Result from post-test}

After the teaching research, the students in the two groups took another test. SPSS software is again applied into the analysis of the data. Since the samples are small and the groups are independent, the appropriate test is again the t-test for independent samples. The critical value of $t$ for 5 percent level and $58 \mathrm{df}$ in a two-tailed test is 2.000 . Table 2 shows that the t- value for the comparison of achievements between the two groups is 5.540, which exceeds the critical value of 2.000 . Furthermore, the mean of the experimental group is higher than that of the control group. Therefore, it comes to the conclusion that the achievements of the experimental group are significantly better than those of the control group.

TABLE II. COMPARISON OF ACHIEVEMENTS BETWEEN THE TWO GROUPS

\begin{tabular}{|l|l|l|l|}
\hline \multirow{2}{*}{} & \multicolumn{2}{|l|}{ Group } & \multirow{2}{*}{$\mathrm{t}$} \\
\cline { 2 - 3 } & experimental control & \\
\hline Mean & 72.250 & 65.850 & \multirow{2}{*}{5.540} \\
\hline SD & 4.991 & 5.098 & \\
\hline
\end{tabular}

\section{B. Comparison and discussion}

In this present study, the teacher applied PBL in the experimental group and traditional teaching method in the control group. The contrast between the two groups is striking. To sum up, the differences between the experimental group and the control group are attributed to the different classroom climates. The control group adopts traditional teaching approach in which the teacher dominates the whole learning process and students are ignorant of the responsibilities for learning. When the teaching is learner-centered in the experimental group, the classroom climate changes in ways that accomplish two objectives. First, the teacher and students aim to create a climate conductive to learning, meaning that they work to establish an environment that positively affects how much and how well students learn. Secondly, the teacher and students aim to create environments where students do
Note: maximum score $=100 \mathrm{n} 1=30 \mathrm{n} 2=30 \mathrm{P}<.05 \mathrm{~d}=58$ as learners, and act in ways that support the learning efforts of others. As for the experimental group, the success of PBL is attributed to critical and creative thinking, effective collaboration, and versatile communication as far as the students are concerned. PBL benefits the students by fostering student-centered learning and in-depth learning, thus achieving higher level of learning and upholding lifelong learning. In addition, PBL reinforces interpersonal skills and teamwork. Meanwhile, the teacher-student relationship is enriched.

\section{CONCLUSION}

With the help of the experimental lesson on Jane Eyre, an innovative method of Problem-based Learning in literature teaching has been proposed, consisting of seven equally important stages: group setting, problem identification, idea 
generation, learning issues, self-directed learning, synthesis and application, reflection and feedback. An empirical research has been conducted to evaluate the effectiveness of PBL compared with traditional teaching approach and instruction by pre-test and post-test. Based on the results of the current research, the conclusion has been drawn that PBL is more effective than traditional teaching approach and instruction due to the effective classroom climates. Needless to say, the present research is far from perfect because of some objective and subjective limitations. PBL in literature teaching calls for the further study on the relationship among the problem, the knowledge, the resource, and the solution.

\section{ACKNOWLEDGEMENT}

This paper is supported by the Fundamental Research Funds for the Central Universities (WUT: 2018VI016) and the Teaching \& Research Project of School of Foreign Languages (WY-1705).

\section{REFERENCES}

[1] Howard S. Barrows MD. Problem-based Learning: An Approach to Medical Education [M]. Springer Publishing Company, 1980

[2] Muhammad Athar Hussain, Muhammad Nafees, Nabi Bux Jumani. Second Language Learners' Achievement in Literature through Problem-Based Learning Method [J]. Journal of the Scholarship of Teaching and Learning, 2009, 9(3): 87-94

[3] Olivera Gajic. Problem Based Learning as a Literature Teaching Strategy: Literary Abilities, Critical Attitude, Creative Thinking [M] Scholars' Press, 2014

[4] Wang Jie. On the Application of PBL in the Teaching of English in College as a Supplementary Approach [D]. Shanghai International Studies University, 2005

[5] Miao Zhangyan. A Study on Application of PBL in College English Teaching [D]. Anhui University, 2014

[6] Zhang Lei. An Experimental Study of Problem-Based Learning in College English Writing [D]. Hangzhou Normal University, 2007

[7] Chen Limin. Application of Problem-Based Learning Model in English Majors' Writing Course [D]. Sichuan International Studies University, 2014

[8] Chen Yanling. The Research on College English Listening Teaching Mode: PBL [D]. Anhui University, 2013

[9] Li Jing. On the Application of Problem-based Learning in College Oral English Teaching [D]. Anhui University, 2013

[10] Wang Wei. A Study on the Application of Problem-based Learning (PBL) in College English Reading [D]. Liaoning Normal University, 2014 